Tạp chí Khoa học và Công nghệ biển T11 (2011). Số 3. Tr 45 - 56

\title{
Ô NHIỄM MÔI TRƯờnG VEN BIỂN TẠI KHU VỰC KHAI THÁC SA KHOÁNG TITAN Ở THIỆN ÁI, HUYỆN BẮC BÌNH, TỈNH BİNH THUẬN
}

\author{
LÊ NGỌC THANH, NGUYẼ̃N QUANG DŨNG, NGUYẼ̃N THỌ, \\ DƯƠNG BÁ MẪN, NGUYẼ̃N TH!̣ ÁNH \\ Viện Địa lý Tài nguyên Thành phố Hồ Chí Minh
}

\begin{abstract}
Tóm tắt: Bài báo làm sáng tỏ vấn đề ô nhiễm môi truờng tại khu vục khai thác sa khoáng Titan (Ti) ở Thiện Ái, huyện Bắc Bình, tỉnh Bình Thuận. Đã có sự ô nhiễm dầu khoáng, hoạt độ phóng xa $(\alpha, \beta)$, hưu co, vi khuẩn và nhiễm mặn vào môi trường tại và xung quanh khu vục khai khoáng. Ngoại trù̀ hũu cơ và vi khuẩn, các thành phần ô nhiếm khác bắt nguồn tù hoạt động khai thác sa khoáng. Sự xuất hiện các thành phần ô nhiếm đang đe doạ môi truờng ven biển và công đồng dân cu địa phuơng. Nhiếm mặn vào nuớc ngầm gây thiếu hụt nguồn nuớc sinh hoạt của nguoòi dân. Hoạt động khai thác sa khoáng Titan cũng làm biến đổi nghiêm trọng cảnh quan tư nhiên vùng ven biển. Ô nhiếm môi trường ven biển ở vùng này hiện còn mang tính cục bộ tại chỗ. Nếu quy mô khai thác được mở rộng, việc đánh giá tác động môi truờng và giám sát hoạt động khai thác cần được tiến hành đầy đủ và nghiêm túc để giảm thiểu nhũng tác động tiêu cực đến môi truờng.
\end{abstract}

\section{MỞ ĐÀU}

Khai thác khoáng sản có thể gây tác động tiêu cực đến môi trường sinh thái (McIlhenny, 1969; Aigbedion \& Iyayi, 2007; Renaud et al., 2009). Ở nước ta, Thủ tướng Chính phủ đã phê duyệt chiến lược Quốc gia về ngăn chặn, ứng phó và giảm nhẹ các thảm hoạ tự nhiên (Quyết định 172/2007 QĐ TTg), trong đó có đề cập đến việc quản lý khai thác khoáng sản một cách hợp lý. Tuy nhiên, hoạt động này ở nước ta hiện nay được cho là đã và đang gây ra những tác động tiêu cực đến môi trường. Khai thác khoáng sản có thể ảnh hưởng tiêu cực đến chất lượng nước ngầm (Bùi Học, 2005). Khai thác Titan khá phổ biến ở nước ta với các quặng đang khai thác nằm ở các đụn cát và các bãi ở vùng ven biển từ Hà Tĩnh đến Vũng Tàu, nhiều nhất là dọc theo bờ biển miền Trung từ Thừa Thiên-Huế đến Phú Yên (Trịnh Thế Hiếu, 2010). Tại vùng bờ biển Quảng Nam, các mẫu đá kết quặng Titan có nguồn gốc phong hoá lục địa từ đá gơnai (gneiss) nằm trong hệ thống các cồn cát nguồn gốc biển-gió tuổi Holocen $\left(\mathrm{mvQ}_{1}{ }^{2-3}\right)$ đã được phát hiện (Trịnh Thế Hiếu, 2010). Tuy nhiên, việc khai thác tài nguyên khoáng sản khu vực này vẫn còn nhiều bất cập (Trịnh Thế Hiếu, 2006). Gần đây, việc khai thác sa khoáng Titan tại huyện Bắc Bình, tỉnh 
Bình Thuận cũng đang được dư luận quan tâm, đặc biệt là về những tác động đến môi trường ven biển và đời sống của người dân địa phương. Theo UBND tỉnh Bình Thuận, hiện có 18 dự án khai thác sa khoáng Titan trên địa bàn. Bài báo trình bày kết quả đo đạc địa vật lý và phân tích ô nhiễm môi trường do khai thác Titan tại khu vực Thiện Ái thuộc huyện Bắc Bình, tỉnh Bình Thuận.

\section{KHU VỰC VÀ PHƯƠNG PHÁP NGHIÊN CÚU}

\section{Khu vực nghiên cứu}

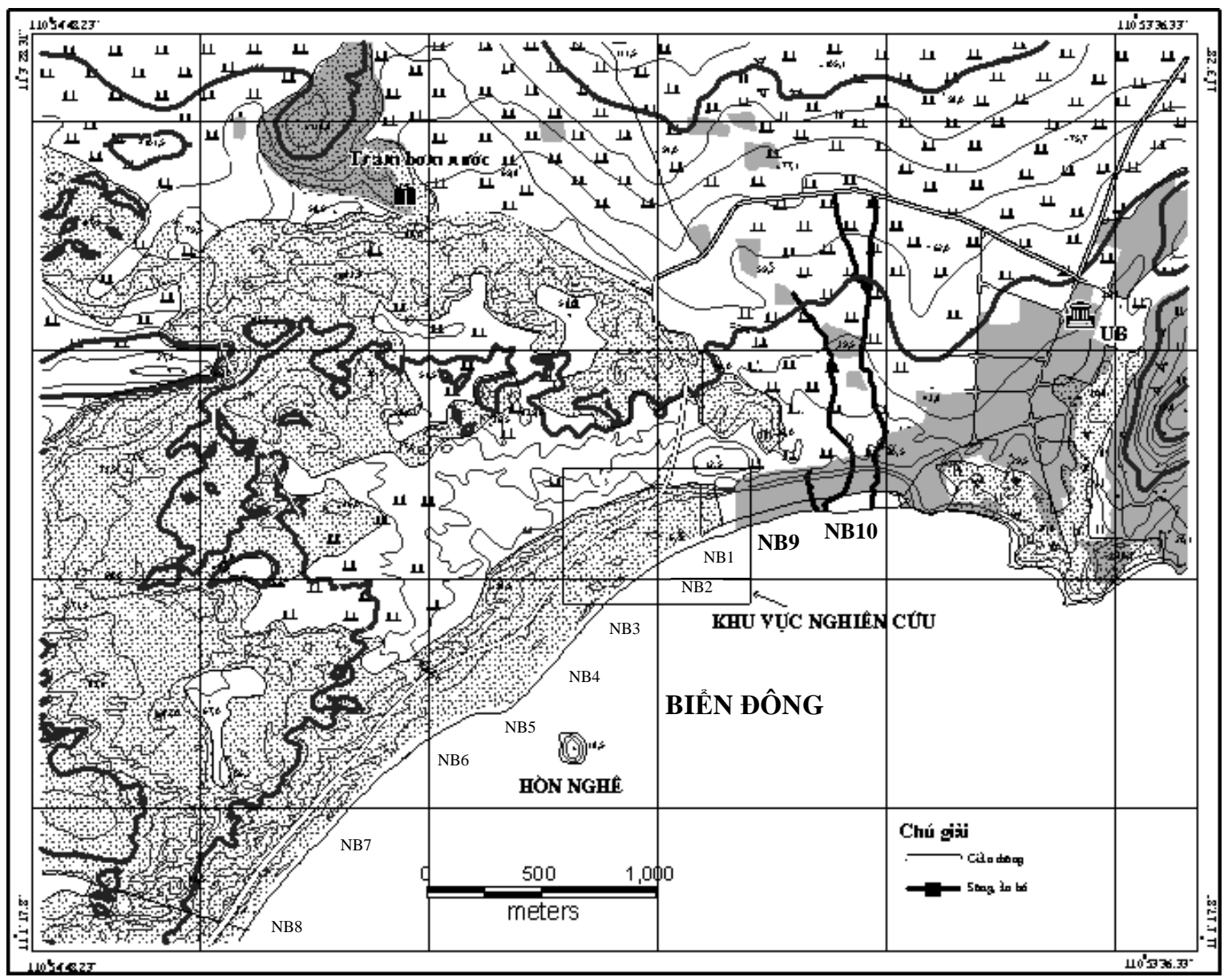

Hình 1: Khu vực nghiên cứu

Khu vực nghiên cứu nằm dọc bờ biển, phần lớn thuộc xã Hòa Thắng và một phần thuộc xã Hồng Phong, huyện Bắc Bình, tỉnh Bình Thuận (hình 1). Tại đây hiện có 4 công ty 
được cấp giấy phép khai thác sa khoáng Titan từ năm 2007. Các địa điểm khai thác trải dài khoảng $2 \mathrm{~km}$ với tổng diện tích là 125 ha. Quá trình khai thác Titan được tiến hành bằng cách đào các hố sâu (có thể đến $12 \mathrm{~m}$ ), sau đó bơm nước lẫn cát chứa quặng từ dưới hố lên và đưa vào các thiết bị đặt trên mặt đất để tuyển quặng. Nước thải và cát sau khi tuyển quặng được đổ ra khu vực bên cạnh. Hoạt động khai thác Titan đã làm thay đổi địa hình trong khu vực, trong đó rõ nhất là sự hình thành những hố lớn do khai thác cát và những đồi cát do tích tụ cát sau khi tuyển quặng. Một số hồ chứa nước thải và nước cấp cho quá trình tuyển sa khoáng đã hình thành trong khu vực mỏ. Tại một số điểm, nước thải được đưa thẳng ra biển. Ngoại trừ chất lượng nước biển ven bờ được khảo sát dọc theo hơn $2 \mathrm{~km}$ bờ biển, tất cả các đo đạc khác được tiến hành trong một phạm vi hẹp như trong hình 1.

\section{Các phương pháp nghiên cứu}

Chất lượng nước sử dụng để khai thác sa khoáng, nước thải sau khai thác, nước ngầm và nước biển ven bờ được xác định qua việc lấy mẫu, đo đạc tại hiện trường và phân tích mẫu trong phòng thí nghiệm. Các đặc trưng của môi trường đất khu vực khai thác sa khoáng cũng được xác định tương tự. Phương pháp đo sâu điện được áp dụng để khảo sát sự xâm nhập mặn vào môi trường đất.

\section{1. Đo sâu điện}

Đo sâu điện được thực hiện tại 30 điểm (tháng 10-11/2009) theo 3 tuyến với khoảng cách thiết bị $\mathrm{AB} / 2_{\max }=150 \mathrm{~m}$, khoảng cách giữa các điểm đo từ $30-60 \mathrm{~m}$ và khoảng cách giữa các tuyến đo từ $70-130 \mathrm{~m}$. Kết quả phân tích định lượng các đường cong đo sâu điện bằng phần mềm IPI2Win cho phép tách ra các lớp địa điện theo chiều sâu và xác định giá trị điện trở suất của các lớp tương ứng. Liên kết các giá trị điện trở suất và chiều sâu theo các lớp khác nhau cho phép xác định ranh giới nhiễm mặn trong khu vực nghiên cứu.

\subsection{Phân tích và xử lý các số liệu đo môi trường}

Khảo sát thực địa được tiến hành trong tháng 10-11/2009 và tháng 5/2010. Nước sử dụng để khai thác sa khoáng được lấy tại 2 công ty đang khai thác với các chỉ tiêu $\mathrm{pH}$, $\mathrm{COD}, \mathrm{Cl}^{-}, \mathrm{SS}, \mathrm{NH}_{4}{ }^{+}$và tổng Coliform. Nước thải sau khai thác được lấy tại 4 hồ chứa của các công ty khai thác với các chỉ tiêu $\mathrm{pH}, \mathrm{EC}, \mathrm{COD}, \mathrm{SS}, \mathrm{Cl}^{-}, \mathrm{NH}_{4}{ }^{+}$, tổng $\mathrm{Fe}, \mathrm{Zn}, \mathrm{Pb}$, tổng Coliform, dầu khoáng, Ti và hoạt độ phóng xạ $(\alpha, \beta)$. Nước ngầm được khảo sát tại giếng của 10 hộ dân trong khu vực với các chỉ tiêu $\mathrm{pH}, \mathrm{Cl}^{-}$, độ cứng toàn phần, $\mathrm{COD}, \mathrm{NH}_{4}{ }^{+}$, $\mathrm{NO}_{2}^{-}, \mathrm{NO}_{3}{ }^{-}$, tổng $\mathrm{Fe}$, TDS, $\mathrm{Zn}, \mathrm{Pb}, \mathrm{CN}^{-}$, As, tổng Coliform, Ti, hoạt độ phóng xạ $(\alpha, \beta)$. Nước biển ven bờ được khảo sát tại 8 điểm gần các khu vực khai thác và các hộ dân với các chỉ tiêu $\mathrm{EC}, \mathrm{Cl}^{-}, \mathrm{SS}, \mathrm{NH}_{4}{ }^{+}$, tổng $\mathrm{Fe}, \mathrm{Zn}, \mathrm{Pb}$, dầu khoáng, Ti, hoạt độ phóng xạ $(\alpha, \beta)$. 
Mẫu đất được lấy tại các khu vực khai thác sa khoáng (4 điểm) và tại các hộ dân lân cận (4 điểm) với các chỉ tiêu $\mathrm{pH}_{\mathrm{KCl}}, \mathrm{EC}, \mathrm{Cl}^{-}, \mathrm{As}, \mathrm{Pb}, \mathrm{Zn}, \mathrm{Fe}$ và Ti.

Các tiêu chuẩn đánh giá mẫu nước phân tích gồm: (1) pH (theo TCVN 6492-1999), (2) COD (TCVN 6491-2000), (3) SS (TCVN 6625-2000), (4) $\mathrm{Cl}^{-}$(TCVN 6194-1996), (5) EC (EC-meter), (6) $\mathrm{NH}_{4}-\mathrm{N}$ (TCVN 5988-1995), (7) $\mathrm{NO}_{2}-\mathrm{N}$ (TCVN 6178-1996), (8) $\mathrm{NO}_{3}$ N (TCVN 6180-1996), (9) TDS (TCVN 4560-1988), (10) Độ cứng toàn phần (TCVN 6224-1996), (11) Tổng Coliform (TCVN 6187:2-1996), (12) Ti (SMEWW 3500-Ti-2000), (13) Dầu khoáng (OCMA 220), (14) hoạt độ phóng xạ $\alpha$ (ISO 9696-1992), (15) hoạt độ phóng xạ $\beta$ (ISO 9697-1992), (16) Tổng Fe (TCVN 6177-1996), (17) Zn (TCVN 61931996), (18) Pb (TCVN 6193-1996), (19) CN (TCVN 6181-1996), (20) Cd (TCVN 61931996) và (21) As (TCVN 6626-2000). Các tiêu chuẩn đánh giá mẫu đất phân tích gồm: (1) $\mathrm{pH}_{\mathrm{KCl}}$ (TCVN 5979-1995), (2) EC (TCVN 6650-2000), (3) $\mathrm{Cl}^{-}$(TCVN 7572-15:2006), (4) các kim loại nặng As, Pb, Zn, Fe (TCVN 6649-2000) và (5) Ti (TCVN 6496-1999). Số liệu môi trường được so sánh với các quy chuẩn Quốc gia tương ứng (bảng 1).

Bảng 1: So sánh kết quả phân tích với các quy chuẩn trong nước về môi trường

\begin{tabular}{|c|c|c|}
\hline STT & Loại mẫu & Quy chuẩn so sánh \\
\hline 1 & Đất & QCVN 03:2008/BTNMT \\
\hline 2 & Nước biển ven bờ & QCVN 10:2008/BTNMT \\
\hline 3 & Nước ngầm & QCVN 09:2008/BTNMT \\
\hline 4 & Nước sử dụng khai thác & QCVN 09:2008/BTNMT \\
\hline 5 & Nước thải & TCVN 5945: 2005 \\
\hline
\end{tabular}

\section{KẾT QUẢ VÀ THẢO LUẬN}

\section{Xâm nhập mặn vào môi trường đất}

Xâm nhập mặn được phát hiện từ mặt đất xuống độ sâu khoảng $10 \mathrm{~m}$ qua trị số điện trở suất thấp $(<10 \Omega \mathrm{m})$. Ranh giới nhiễm mặn được thể hiện trong hình 2 (khu vực nhiễm mặn nằm bên trái của đường ranh giới nhiễm mặn). Xâm nhập mặn trong khu vực này là hậu quả của việc sử dụng nước nhiễm mặn để tuyển quặng và thải bỏ trực tiếp nước mặn ra môi trường đất. Ở xa các điểm khai thác (khu vực bên phải của đường ranh giới nhiễm mặn) không có sự xâm nhập mặn vào đất. 


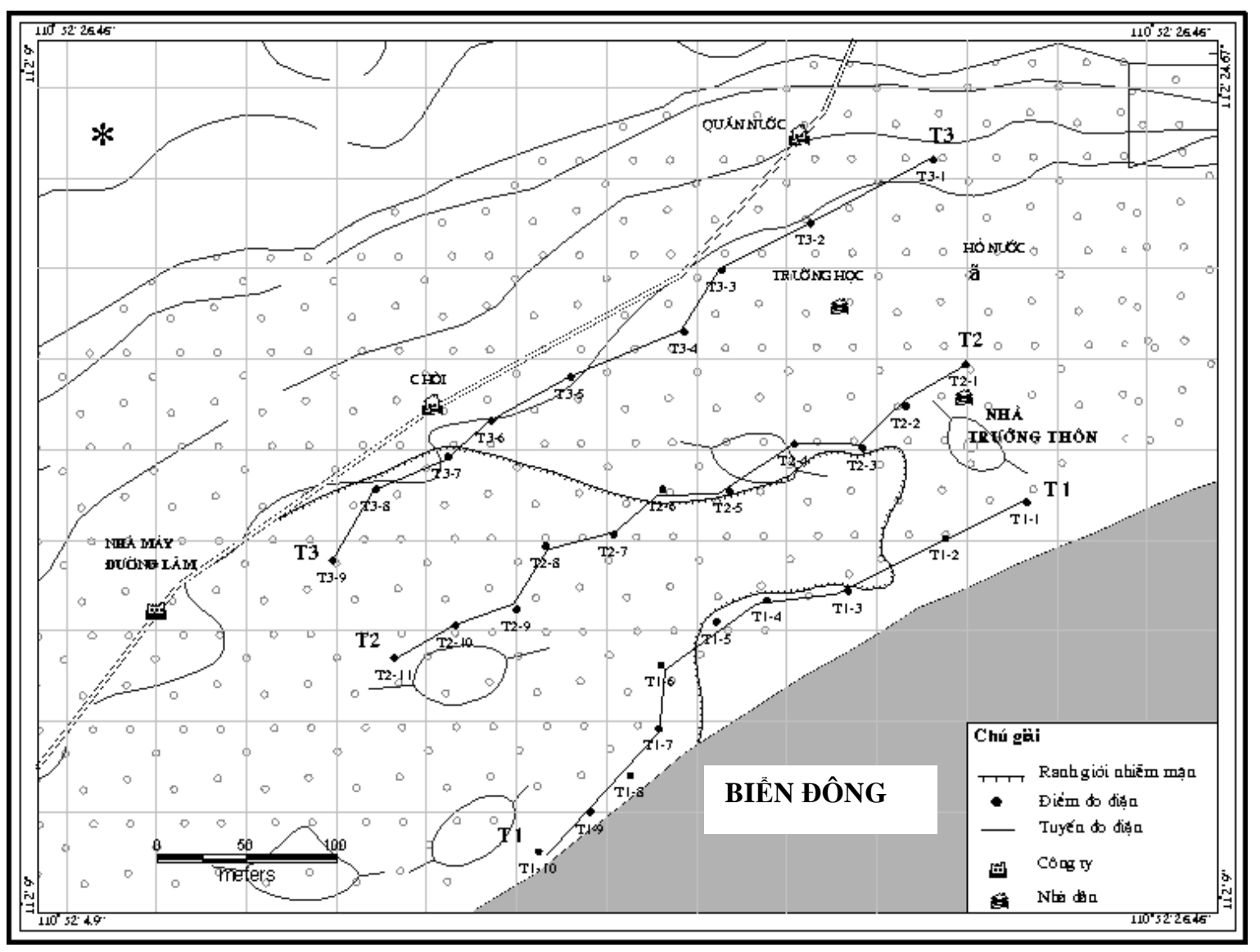

Hình 2: Ranh giới nhiễm mặn tại khu vực nghiên cứu

\section{Nước sử dụng để khai thác sa khoáng và nước thải sau khai thác}

Ngoại trừ hàm lượng $\mathrm{Cl}^{-}$cao do nhiễm mặn, nước được các công ty sử dụng để khai thác sa khoáng Titan có $\mathrm{pH}, \mathrm{NH}_{4}-\mathrm{N}$ và tổng Coliform nằm trong giới hạn cho phép theo QCVN 09:2008/BTNMT (bảng 2).

Mặc dù nước đầu vào để khai thác sa khoáng không bị nhiễm bẩn, nước thải sau khai thác có một số chỉ tiêu (chất rắn lơ lửng, dầu khoáng, hoạt độ phóng xạ) vượt tiêu chuẩn đối với nước thải công nghiệp (TCVN 5945-2005, cột B) (hình 3). Nước thải tại cả 4 điểm khảo sát đều có hàm lượng muối vượt quy chuẩn cho phép đối với nước thải công nghiệp (qua chỉ tiêu $\mathrm{Cl}^{-}$). Chỉ một điểm có hàm lượng dầu khoáng vượt tiêu chuẩn cho phép. Tại hầu hết các điểm khảo sát đều có hoạt độ phóng xạ cao (ngoại trừ điểm 3 có hoạt độ phóng xạ $\alpha$ thấp). Như vậy, chính nước thải sau khai thác sa khoáng là nguyên nhân gây ô nhiễm môi trường tại khu vực nghiên cứu. Nước thải sau khai thác được đưa ra 
môi trường mà không qua xử lý là nguy cơ tiềm ẩn cho môi trường ven biến, đặc biệt là các đối tượng sinh học, trong đó có con người.

Bảng 2: Chất lượng nước sử dụng để khai thác sa khoáng Titan

\begin{tabular}{|c|c|c|c|c|c|}
\hline STT & Chỉ tiêu & Mẫu 1 & Mẫu 2 & Đon vị & $\begin{array}{c}\text { QCVN } \\
\text { 09:2008/BTNMT }\end{array}$ \\
\hline 1 & $\mathrm{pH}$ & 8,18 & 7,66 & & $5,5-8,5$ \\
\hline 2 & $\mathrm{SS}$ & 4,0 & 7,3 & $\mathrm{mg} / \mathrm{l}$ & - \\
\hline 3 & $\mathrm{Cl}^{-}$ & $1.919,0$ & $17.285,1$ & $\mathrm{mg} / \mathrm{l}$ & 250 \\
\hline 4 & $\mathrm{NH}_{4}-\mathrm{N}$ & $\mathrm{KPH}^{4}$ & 0,1 & $\mathrm{mg} / \mathrm{l}$ & 0,1 \\
\hline 5 & Tồng Coliform & $<1$ & $<3$ & MPN/100 $\mathrm{ml}$ & 3 \\
\hline
\end{tabular}

${ }^{1}$ Nước sủ dụng để khai thác sa khoáng tại Công ty Đường Lâm

${ }^{2}$ Nước sử dụng để khai thác sa khoáng tại Công ty Tài Nguyên

${ }^{3}$ QCVN 09:2008/BTNMT: Quy chuẩn kỹ thuật Quốc gia về chất luợng nuoóc ngầm

${ }^{4} \mathrm{KPH}=$ Không phát hiện

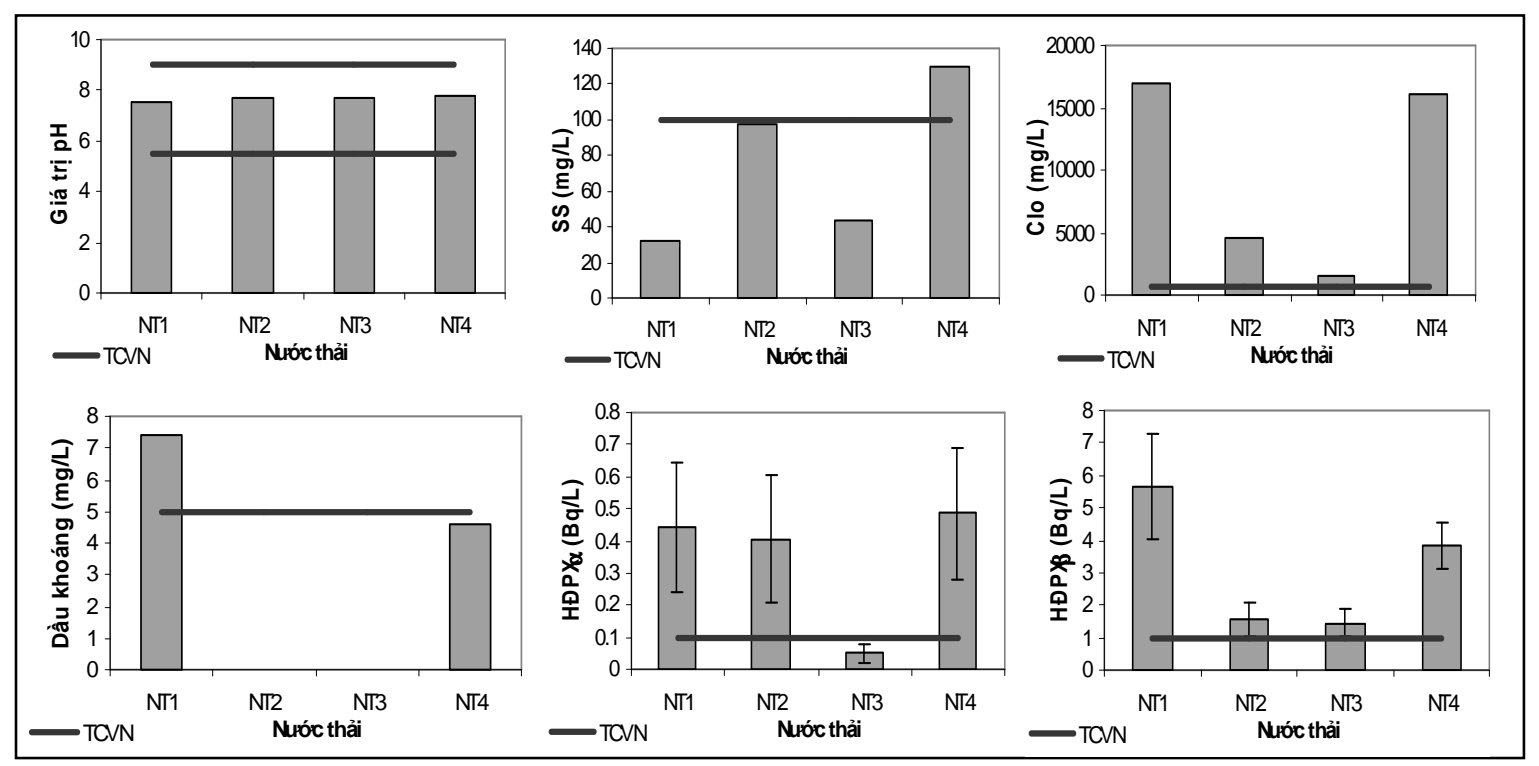

Hình 3: Các chỉ tiêu nước thải vượt quy chuẩn Quốc gia (TCVN 5945-2005, cột B) 


\section{Chất lượng nước ngầm}

Một số chỉ tiêu hoá lý và phóng xạ vượt giới hạn cho phép đối với nước ngầm tại một số vị trí. Các chỉ tiêu vượt quy chuẩn Việt Nam (QCVN 09:2008/BTNMT) là độ cứng toàn phần (2/10 mẫu), $\mathrm{COD}(1 / 10), \mathrm{Cl}^{-}(3 / 10), \mathrm{NH}_{4}-\mathrm{N}(3 / 10), \mathrm{NO}_{3}-\mathrm{N}(1 / 10)$, hoạt độ phóng xạ $\alpha(2 / 10)$ và hoạt độ phóng xạ $\beta(1 / 10)$. Ngoài ra còn có dấu hiệu nhiễm chì $(\mathrm{Pb})$ tại 1 điểm khảo sát (hình 4). Nước ngầm trong khu vực nghiên cứu đã bị nhiễm mặn, hữu cơ và phóng xạ. Hàm lượng $\mathrm{Cl}^{-}$cao nhất vào tháng 11/2009 là $1.654 \mathrm{mg} / \mathrm{l}$. Các giếng 4,5 và 6 có hàm lượng $\mathrm{Cl}^{-}$cao (hình 4) đều nằm trong khu vực bị nhiễm mặn theo số liệu đo sâu điện. Ngược lại, các giếng nằm bên phải đường ranh giới nhiễm mặn đều có trị số $\mathrm{Cl}^{-}$ thấp. Vào tháng 5/2010, hàm lượng $\mathrm{Cl}^{-}$cao nhất được ghi nhận là $1.250 \mathrm{mg} / \mathrm{l}$ (giếng 5). Các trị số này cao hơn nhiều so với quy chuẩn Việt $\mathrm{Nam}$ về chất lượng nước ngầm $\left(\mathrm{Cl}^{-}\right.$ $250 \mathrm{mg} / \mathrm{l})$. Sự nhiễm bẩn hữu cơ có thể xuất phát từ nhiều nguyên nhân, trong đó có thể do tập quán sinh hoạt của người dân địa phương. Tuy nhiên, sự nhiễm mặn và hoạt độ phóng xạ bắt nguồn từ hoạt động khai thác sa khoáng tại chỗ.

\section{Chất lượng nước biển ven bờ}

Hoạt động khai thác sa khoáng gây ô nhiễm nước biển ven bờ, thể hiện qua sự tăng cao hoạt độ phóng xạ $\alpha$ và hoạt độ phóng xạ $\beta$ (hình 5). Đây chính là hệ quả của việc đưa nước thải chưa qua xử lý ra biển. Không có sự khác biệt về hoạt độ phóng xạ trong nước biển ven bờ gần các công ty khai thác và gần các hộ dân. Tuy nhiên, tại 2 điểm cách xa khu vực khai thác (NB9 và NB10), hoạt độ phóng xạ thấp hơn nhiều so với các điểm tại khu vực khai thác (Từ NB1 đến NB8) (hình 1 và 6 ). Kết quả này cho thấy chưa có sự lan truyền hoạt độ phóng xạ ra xa khu vực khai thác.

\section{Môi trường đất khu vực khai thác sa khoáng}

Bảng 3: Các thông số môi trường đất khu vực khai thác sa khoáng Titan

\begin{tabular}{|c|c|c|c|c|c|c|}
\hline Thông & Đơn & Cụ̂c tiểu & Cục đại & Trung & \multicolumn{2}{|c|}{ QCVN 03:2008/BTNMT } \\
\cline { 5 - 7 } & & & & bình & Đất dân sinh & Đất công nghiệp \\
\hline $\mathrm{pH}$ & - & 7,76 & 9,48 & 8,62 & - & - \\
\hline $\mathrm{EC}$ & $\mu \mathrm{S} / \mathrm{cm}$ & 322 & 4,440 & 1483,13 & - & - \\
\hline $\mathrm{Cl}^{-}$ & $\%$ & 0,001 & 0,12 & 0,04 & - & - \\
\hline $\mathrm{As}$ & $\mathrm{mg} / \mathrm{kg}$ & 1,20 & 2,55 & 1,79 & 12 & 12 \\
\hline $\mathrm{Pb}$ & $\mathrm{mg} / \mathrm{kg}$ & 0,50 & 5,87 & 2,73 & 120 & 300 \\
\hline $\mathrm{Fe}$ & $\%$ & 0,17 & 0,53 & 0,35 & - & - \\
\hline $\mathrm{Zn}$ & $\mathrm{mg} / \mathrm{kg}$ & 4,29 & 14,10 & 10,11 & 200 & 300 \\
\hline $\mathrm{Ti}$ & $\mathrm{mg} / \mathrm{kg}$ & 83,58 & 134,88 & 105,32 & - & - \\
\hline
\end{tabular}


Môi trường đất tại khu vực khai thác chưa bị ô nhiễm (bảng 3). Hàm lượng Titan trong đất dao động từ 83,58 đến 134,88 mg/kg. Hàm lượng các kim loại nặng $(\mathrm{As}, \mathrm{Pb}, \mathrm{Zn}$ ) nằm trong giới hạn cho phép theo QCVN 03:2008/BTNMT (Quy chuẩn kỹ thuật Quốc gia về giới hạn cho phép của kim loại nặng trong đất).
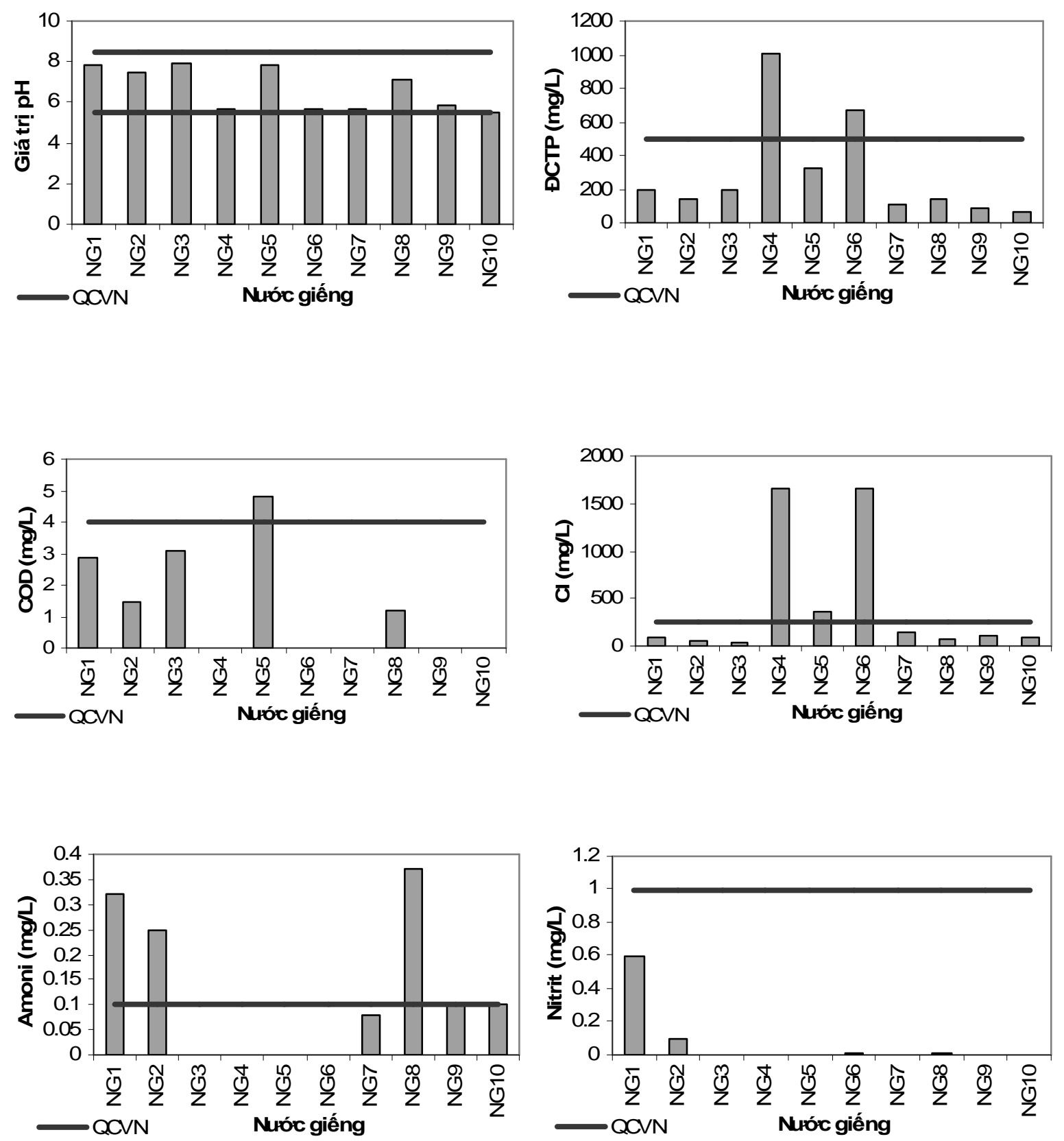

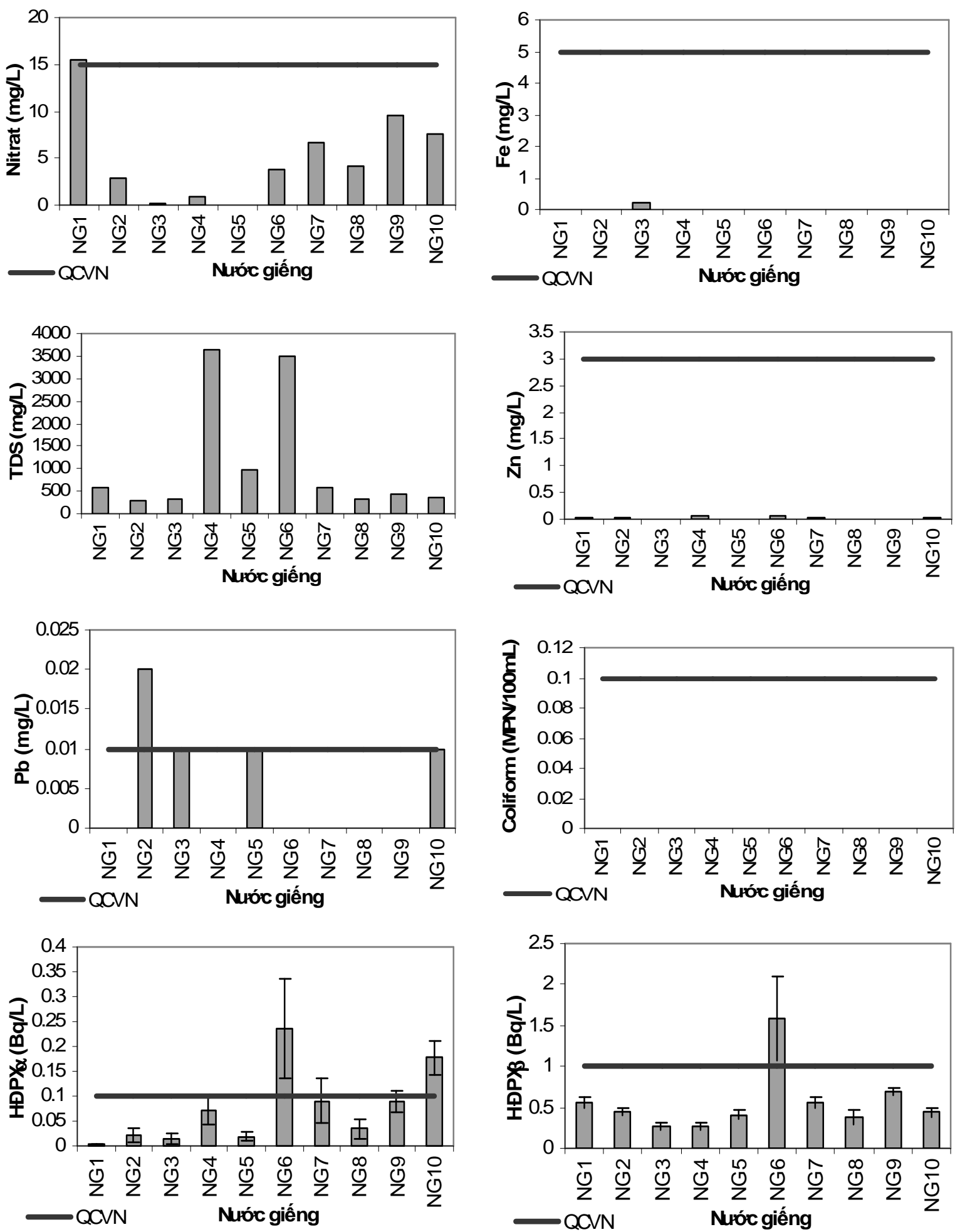

Hình 4: Chất lượng nước ngầm trong khu vực nghiên cứu so sánh với Quy chuẩn Quốc gia về chất lượng nước ngầm (QCVN 09:2008/BTNMT) 


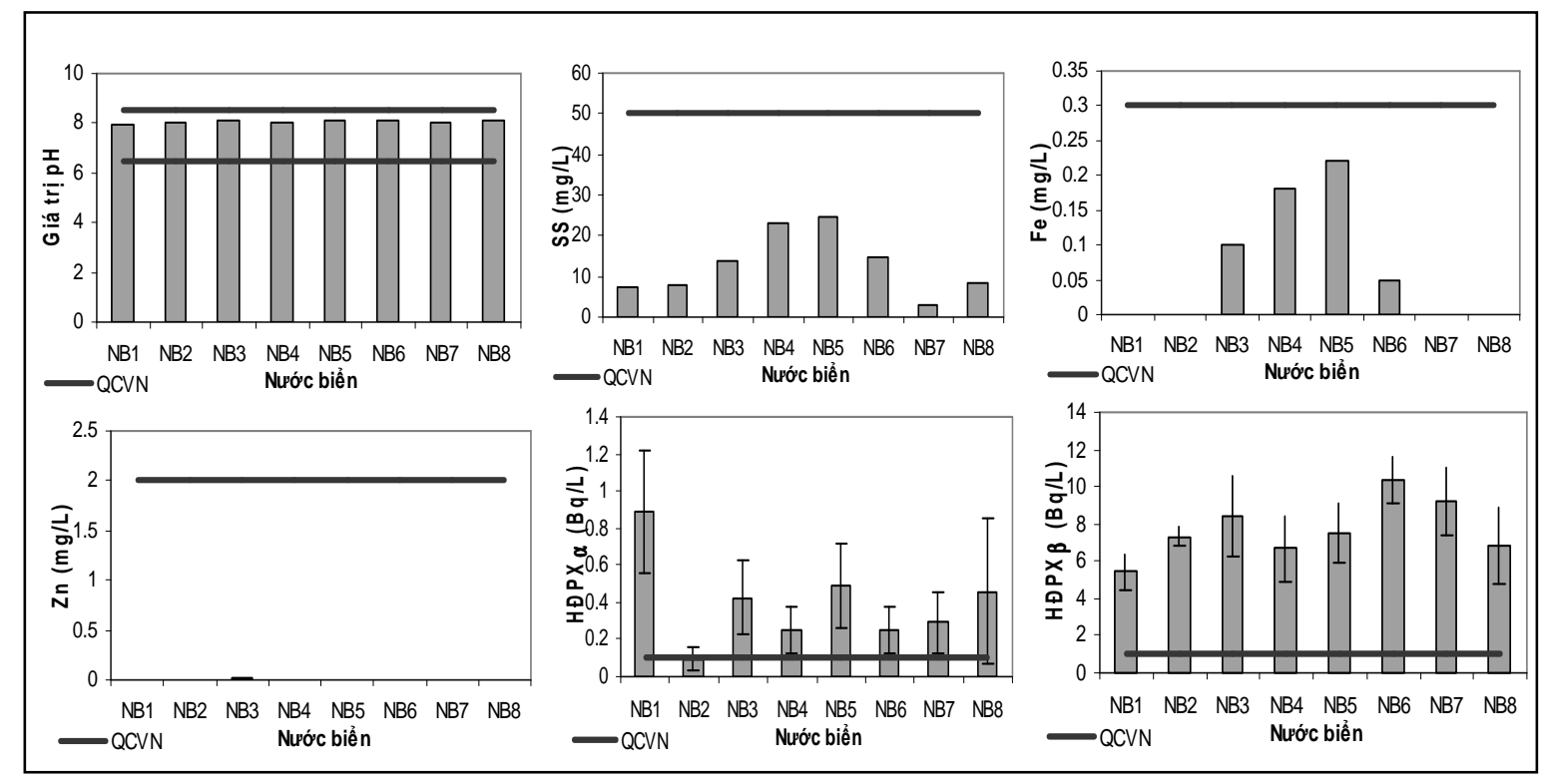

Hình 5: Chất lượng nước biển ven bờ so sánh với quy chuẩn Quốc gia (QCVN 10:2008/BTNMT)

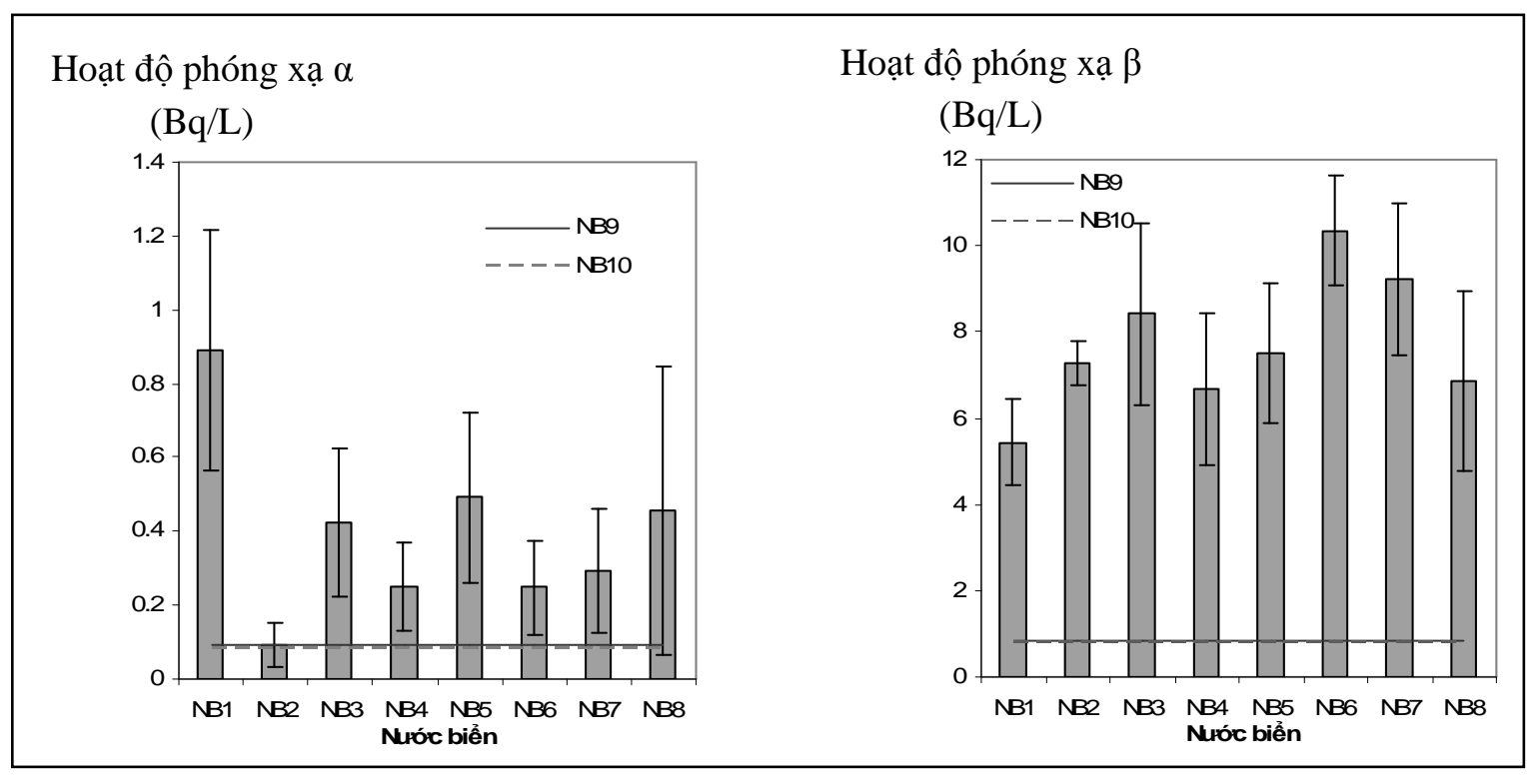

Hình 6: So sánh hoạt độ phóng xạ ( $\alpha$ và $\beta$ ) giữa các điểm tại khu vực khai thác (NB1 đến NB8) và các điểm xa khu vực khai thác (NB9, NB10) 


\section{KẾT LUẬn}

Môi trường ven biển tại khu vực khai thác sa khoáng Titan đã có dấu hiệu ô nhiễm, chủ yếu là (1) dầu khoáng, (2) hoạt độ phóng xạ $(\alpha, \beta),(3)$ hữu cơ và vi khuẩn, và (4) xâm nhập mặn. Ngoại trừ hữu cơ và vi khuẩn, các thành phần ô nhiễm khác bắt nguồn từ việc đưa nước thải chưa xử lý vào môi trường. Nhiễm mặn vào nước ngầm làm khan hiếm nguồn nước ngọt và gây khó khăn cho các hộ dân gần khu vực khai thác. Ngoài ra, cảnh quan tự nhiên của khu vực cũng bị biến đổi nghiêm trọng do hoạt động khai thác. Việc khai thác Titan đã và đang gây ra những tác động tiêu cực đến môi trường sinh thái ở vùng này, tương tự như đã xảy ra ở vùng bờ biển Quảng Nam. Với mức độ khai thác như hiện nay, ô nhiễm môi trường còn mang tính cục bộ tại chỗ, nhưng nếu quy mô khai thác được mở rộng, đặc biệt là ở những khu vực đông dân cư hoặc phát triển du lịch, công tác đánh giá tác động môi trường cần phải được tiến hành đầy đủ và nghiêm túc để có biện pháp ngăn ngừa kịp thời và hợp lý. Hiện nay, Sở Khoa học và Công nghệ tỉnh Bình Thuận đang lập quy trình khai thác Titan theo hướng bền vững và an toàn. Đây là việc làm rất cấp bách trong bối cảnh mở rộng khai thác Titan như hiện nay.

\section{TÀI LIỆU THAM KHẢO}

1. Aigbedion I. \& Iyayi S.E., 2007. Environmental effect of mineral exploitation in Nigeria. International Journal of Physical Sciences 2 (2), 33-38.

2. Bùi Học, Phạm Khánh Huy, Hoàng Thị Minh Thảo, 2005. Groundwater Management in Vietnam (www.idm.gov.vn/Nguon_luc/Xuat_ban/2005/ B25/b26.htm (truy cập ngày 28/8/2010).

3. Mcilhenny W.F., 1969. Polutional Aspects of Marine Mineral Exploitation. Offshore Technology Conference, 18-21 May, Houston, Texas.

4. Renaud F., Bordes J.L.M. \& Mohammadnia M., 2009. Groundwater and Human Security - Case Studies. Report of the 3rd Workshop, Shiraz, I.R. Iran, 16-18 May 2009.

5. Trịnh Thế Hiếu (2006). Tài nguyên khoáng sản rắn vùng bờ tỉnh Quảng Nam Hiện trạng khai thác và vấn đề môi trường. Tạp chí Khoa học và Công nghệ biển T6, 4, 37-47.

6. Trịnh Thế Hiếu, Đỗ Minh Tiệp, Phạm Bá Trung, 2010. Bàn về nguồn gốc quặng Titan ở vùng bờ Quảng Nam. Tạp chí Khoa học và Công nghệ biển T10, 4, 29-37. 


\title{
COASTAL POLLUTION AT THE SITE OF TITANIUM EXPLOITATION IN THIEN AI AREA, BAC BINH DISTRICT, BINH THUAN PROVINCE
}

\author{
LE NGOC THANH, NGUYEN QUANG DUNG, NGUYEN THO, \\ DUONG BA MAN, NGUYEN THI ANH
}

\begin{abstract}
Summary: This paper clarifies the environmental pollution issue at the Titanium exploitation site of Thien Ai, Bac Binh district, Binh Thuan province. Pollution of mineral oil, radioactivity $(\alpha, \beta)$, organic and bacteria (total coliforms) and salinisation to the surroundings have been observed. Except organic and bacteria, the other kinds of pollution are stemmed from the exploitation activity. The presence of pollutants is threatening this coastal area and the local community. Groundwater salinisation has caused a lack of freshwater for domestic use of the local people. Titanium exploitation has also dramatically changed the coastal landscape of the area. Currently, the problem of environmental pollution in the area is local. The task of environmental impact assessment and monitoring of exploitation must be fully implemented to minimize the negative environmental impacts if the exploitation scale is extended.
\end{abstract}

Ngày nhận bài: 17 - 11 - 2010

Ngưòi nhận xét: PGS. TS. Trần Đức Thạnh 